\title{
Apakah model discovery learning berhasil meningkatkan pemahaman nilai- nilai komitmen integrasi nasional?
}

\author{
Sae'an ${ }^{\text {a1* }}$ \\ ${ }^{\text {a }}$ SMK N 1 Cilegon \\ ${ }^{1}$ saeanurudin@gmail.com \\ ${ }^{*}$ korespondensi penulis
}

\begin{abstract}
ABSTRAK
Penelitian ini diterapkan untuk melihat peningkatan nilai-nilai komitmen yang terintegrasi secara nasional menggunakan model discovery learning. Subjek penelitian adalah kelas X sebanyak 35 siswa dengan kategori usia $\pm 16-17$ tahun. Tujuan nyata dalam penelitian ini yaitu mengetahui sejauh mana model Discovery learning mampu meningkatkan hasil belajar siswa pada materi integrasi nasional dalam Bhineka Tunggal Ika yang kurang diperhatikan secara langsung. Jenis penelitian ini menggunakan penelitian tindakan kelas dengan pendekatan kualitatif yang dilaksanakan dalam dua siklus. Data primer diperoleh dari kegiatan pembelajaran peserta didik yang dilakukan melalui observasi, tes, dan dokumentasi. Hasil penelitian membuktikan bahwa siklus I diperoleh ketuntasan klasikal dan nilai rerata kelas sebesar 77\% (81) mengalami peningkatan pada siklus II sebesar 91\%(89). Faktor peningkatan terjadi disebabkan: (1) pengumpulan informasi secara terbimbing dalam sumber media online; (2) rasa ingin tahu, kreativitas, dan merumuskan pertanyaan kritis; (3) keberhasilan dalam mengkomunikasikan informasi.
\end{abstract}

Kata kunci: Discovery learning, Peningkatan, Pemahaman, Nilai-nilai Komitmen, Integrasi

\section{ABSTRACT}

This research is applied to see the increase in commitment values that are integrated nationally using the Discovery learning model. The subjects of the study were 35 students in class $X$ with the age category $\pm 16-17$ years. The real objective in this research is to know the extent to which the Discovery learning model is able to improve student learning outcomes on national integration material in Unity in Diversity which is not directly addressed. This type of research uses classroom action research with a qualitative approach carried out in two cycles. Primary data obtained from the learning activities of students conducted through observation, tests, and documentation. The results of the study prove that the first cycle obtained classical completeness and the average grade of 77\% (81) has increased in the second cycle of 91\% (89). The increase factor occurred due to: (1) guided collection of information in online media sources; (2) curiosity, creativity, and formulating critical questions; (3) success in communicating information.

Keywords: Discovery learning, Improvement, Understanding, Commitment Values, Integration

Copyright (C) 2019 Universitas Ahmad Dahlan, All Right Reserved

\section{PENDAHULUAN}

Sekolah Menengah Kejuruan (SMK) merupakan institusi pendidikan dengan tujuan menciptakan lulusan agar mampu mengembangkan potensi peserta didik pada bidang keahlian secara soft skill dan hard skill yang mampu berdaya guna dalam dunia kerja. Potensi tersebut dibentuk secara bertahap dan terus menerus melalui proses pembelajaran serta adaptasi dengan lingkungan belajar. Hal ini identik dengan strategi pembelajaran (Slavin, 2005) dan peran penting sekolah dalam pencapaian kompetensi tersebut. Sebab bagaimanapun kompetensi tercapai (sikap, pengetahuan, dan keterampilan), akan tetapi kompetensi sikap lebih direkomendasikan pihak industri. Artinya nilai-nilai soft skill perlu mendapatkan dukungan semua pihak terkait agar terbentuk menjadi pembiasaan diri.

Faktual di lapangan, berdasarkan tingkat kenakalan remaja yaitu pada jenjang pelajar, kenakalan tertinggi terletak pada peserta didik SMK (Syifaunnufush \& Diana, 2017). Beberapa alasan yang muncul diantaranya peserta didik jenjang SMK mayoritas adalah laki-laki, penekanan pembelajaran praktik lebih domininasi menjadikan kebiasaan yang memiliki jiwa pekerja sehingga lebih banyak menggunakan tenaga dari pada pemikiran. Selain itu ambisi remaja memilikia ambisi yang tinggi. Apabila kondisi tersebut salah dalam lingkungan pergaulan memberikan dampak negatif pada peserta didik tersebut. Dampak yang muncul pada masyarakat diantaranya terbentuknya kelompok-kelompok dengan rekruitmen berkelanjutan, aktivitas yang tidak mengarah penguatan pembelajaran, bahkan tindakan yang membahayakan diri sendiri serta orang lain seperti minum-minuman keras. Hal ini perlu dihindarkan, dan melakukan tindakan yang positif dengan pembentukan soft skill.

Kondisi di atas menjadi tangung jawab semua pihak, meskipun secara amanah bahwa soft skill 
terintegrasi pada guru pengampu $\mathrm{PPkN}, \mathrm{BK}$ dan Pendidikan Agama. Akan tetapi tanpa penguatan dari pihak sekolah yang menjadi komitmen bersama dan kepedulian orang tua terhadap perubahan dan perkembangan anak, maka guru tidak leluasa dalam memberikan keberhasilan peserta didik. Artinya guru hanya mampu memberikan batasan dan pola pikir selama pembelajaran selebihnya lingkungan, orang tua memiliki pengaruh yang lebih besar untuk membatasi pergaulan peserta didik. Beberapa penelitian telah menunjukkan bahwa sikap terhadap partisipasi kelas dapat meningkat ketika pendidikan yang berpusat pada peserta didik diberikan (Lee, 2019).

Melalui pembentukan nilai-nilai toleran, nilainilai damai yang membentuk komitmen integrasi nasional diharapkan peserta didik mampu bersikap dalam pergaulan serta memiliki toleransi yang baik. Karena dalam berkehidup masyarakat baik masyarakat pendidikan maupun masyarakat umum memiliki banyak karakteristik perbedaan yang harus dijunjung tinggi untuk membentuk kesatuan yang padu. Seseorang yang memahamui perbedaan jauh lebih mampu menghargai orang lain. Nilainilai tersebut harus tercermin dalam proses pembelajaran dan terimplementasi dalam kehidupan bermasyarakat.

Hasil pembelajaran pada mata pelajaran Kewarganegaraan dengan kompetensi Integrasi Nasional dalam Bingkai Bhineka Tunggal Ika di tahun pelajaran 2018/2019 dalam rekapitulasi nilai tergolong pada kategori rendah. Sebanyak 6 kelas dengan masing-masing kelas 35-40 orang/peserta didik, dari batas Kriteria Ketuntasan Mengajar (KKM) yaitu 75,0 diperoleh rerata 78,8\% dengan jumlah peserta $65 \%$ (223). Hal ini menunjukkan bahwa pembelajaran belum mencapai KKM dan perlu ditingkatkan.

Angka tersebut, selanjutnya dilakukan analisis deksripsi untuk melihat faktor penyebab dari hasil KKM yang tidak tercapai. Melalui sumber dari guru pengampu sebidang, kepala program studi, waka kurikulum dan waka kesiswaan serta informasi peserta didik dikumpulkan, diperoleh beberapa kesimpulan diantaranya: (1) pemusatan pembelajaran pada peserta didik dengan posisi duduk di belakang; (2) mengajak peserta didik aktif dalam kegiatan pembelajaran seperti memberikan pertanyaan, memberikan kesempatan peserta didik berdiskusi atau seminar; dan (3) pembelajaran secara langsung pada permasalahan yang terjadi pada kehidupan sekitar. Masukan tersebut dikemas ke dalam perencanaan pembelajaran berupa perangkat pembelajaran dengan memilih metode saintifik learning berupa discovery learning.

Discovery leraning merupakan salah satu metode yang dianggap mampu untuk memberikan peran aktif dan kesan pembelajaran secara langsung. Pembelajaran aktif Pembelajaran aktif, yang merupakan bentuk pengajaran yang berpusat pada siswa, diyakini dapat meningkatkan motivasi siswa, menciptakan pelajar yang lebih dinamis dan percaya diri, dan juga dapat membantu dalam menjangkau siswa yang gaya belajarnya tidak responsif terhadap bentuk pengajaran pasif (Bonwell \& Eison, 1991; Gainous \& Martens, 2012; Silberman, 1996; Zmuda, 2008). Selain itu pemilihan metode yang didasarkan melalui penemuan menjadikan peserta didik memiliki pengalaman dari hasil pengamatan lingkungan sekitar (Ali \& Setiani, 2019). Guru dengan metode discovery learning berkesempatan memberikan bimbingan melalui tukar pendapat, diksusi, seminar, membaca mandiri. Metode ini dianggap tepat untuk memberikan pemahaman dan pencapaian kompetensi peserta didik.

\section{METODE}

Jenis penelitian yang digunakan adalah Classroom Action Research (CAR) yang dikembangkan dari model Eliott \& Covington, Sebanyak dua siklus dikemas dalam kompetensi pembelajaran integrasi nasional. Setiap siklusnya sebanyak dua pertemuan. Penguatan pada penelitian ini terletak pada refleksi tindakan dengan masukan berbagai observer dapat meningkatan aktivitas discovery learning yang kurang efektif menjadi lebih efektif. Selain itu pengamatan pada peserta didik lebih terkontrol, kesen peserta yang pasif pada siklus ke dua menjadi lebih aktif. Penelitian ini dilaksanakan di SMK N 1 Cilegon dengan populasi yang digunakan adalah satu kelas sebanyak 35 orang dengan karakteristik usia $\pm 16 / 17$ tahun pada kelas $X$ tahun pelajaran 2018/2019 tepatnya bulan April - Mei 2019.

Model discovery learning dilaksanakan secara berkelompok, terbagi menjadi 6 kelompok terdiri dari 6-7 orang untuk setiap kelompok (Yew \& Schmidt, 2009). Pembagian kelompok didasarkan pada kesediaan peserta didik untuk menjadi koordinator kelompok. Selanjutnya pemilihan anggota kelompok dilakukan secara random. Tujuan utamanya adalah tidak adanya pemaksaan selam proses pembelajaran berlangsung.

Skenario pembelajaran dilakukan dari penerjemahan kompetensi dasar kedalam IPK sebagai berikut: 
Tabel 1. Scenario Pembelajaran Integrasi Nasional terhadap Siklus

\begin{tabular}{|c|c|c|}
\hline \multicolumn{2}{|r|}{ Kompetensi Dasar/IPK } & Siklus \\
\hline 3.9 .1 & $\begin{array}{l}\text { Menyimpulkan konsep } \\
\text { Integrasi Nasional }\end{array}$ & $\begin{array}{l}\text { Siklus } \\
\text { I }\end{array}$ \\
\hline 3.9 .2 & $\begin{array}{l}\text { Menelaah faktor-faktor } \\
\text { Pembentuk Integrasi } \\
\text { Nasional }\end{array}$ & \\
\hline 4.9.1. & $\begin{array}{l}\text { Mempresentasikan hasil } \\
\text { analisis tentang faktor-faktor } \\
\text { pembentuk integrasi } \\
\text { nasional dalam bingkai } \\
\text { Bhinneka Tunggal Ika }\end{array}$ & \\
\hline 3.9 .3 & $\begin{array}{l}\text { Menganalisis tantangan } \\
\text { dalam Menjaga Keutuhan } \\
\text { Negara Kesatuan Republik } \\
\text { Indonesia }\end{array}$ & $\begin{array}{l}\text { Siklus } \\
\text { II }\end{array}$ \\
\hline 3.9 .4 & $\begin{array}{l}\text { Menganalisis peran serta } \\
\text { warga negara dalam } \\
\text { menjaga Persatuan dan }\end{array}$ & \\
\hline 4.9.2. & $\begin{array}{l}\text { Kesatuan Bangsa } \\
\text { Menyaji secara tertulis } \\
\text { hasil analisis tentang } \\
\text { faktor-faktor pembentuk } \\
\text { integrasi nasional dalam } \\
\text { bingkai Bhinneka Tunggal } \\
\text { Ika }\end{array}$ & \\
\hline
\end{tabular}

Ketercapaian pembelajaran mengacu pada standar (80\%) jumlah peserta berada dalam kategori KKM yaitu 80.

Data primer yang diperoleh selama proses pembelajaran yaitu aktivitas guru dan aktivitas peserta didik oleh lembar observasi yang dilakukan observer. Kemampuan kognitif yang dilakukan malalui pre tes dan post test pada setiap siklusnya, selanjutnya rerata pada siklus I dan siklus II diperoleh hasil peningkatan dan tes psikomotor dilakukan dengan melihat aktivitas kelompok dalam memaparkan hasil diskusi atau seminar.

Data yang terkumpul selanjutnya dianalisis untuk melihat ketercapaian ketuntasan pembelajaran menggunakan discovery learning. Penguatan data secara kualitatif diakhir siklus I setelah menerima masukan dari observer diperoleh dengan cara wawancara kepada peserta didik langsung secara perwakilan kelompok. Hal ini dilakukan untuk melihat seberapa mendalam dicovery learning memberikan pengaruh dalam proses pembelajaran serta memberbaiki kualitas pembelajaran pada siklus II.

\section{HASIL DAN PEMBAHASAN}

Deskripsi Kondisi Awal

Berdasarkan hasil observasi dan informasi yang diperoleh dari kelas $\mathrm{X}$ di SMKN 1 Cilegon diperoleh data dari observasi kondisi awal, nilai ulangan harian siswa masih sangat rendah, masih banyak siswa yang tidak mencapai ketuntasan belajar. Data peringkat hasil belajar siswa dapat dilihat pada Tabel 2.

Tabel 2. Data Frekuensi Peringkat Hasil Belajar Kognitif Siswa Prasiklus

\begin{tabular}{ccccc}
\hline \multirow{2}{*}{ No. } & \multirow{2}{*}{ Peringkat } & \multicolumn{3}{c}{ Pra Siklus } \\
\cline { 3 - 5 } & & $\mathrm{F}$ & $\mathrm{P}$ & $\%$ \\
\hline 1 & $90-100$ & 2 & 0,06 & 6 \\
2 & $80-90$ & 12 & 0,34 & 34 \\
3 & $70-80$ & 11 & 0,31 & 31 \\
4 & $60-70$ & 5 & 0,14 & 14 \\
5 & $50-60$ & 4 & 0,12 & 12 \\
6 & $40-50$ & 1 & 0,03 & 3 \\
7 & $<40$ & 0 & 0 & 0 \\
& Jumlah & 35 & 1 & 100 \\
\hline
\end{tabular}

\section{Deskripsi Tindakan Siklus I}

Siklus I dilaksanakan dalam dua kali pertemuan selama 2 jam pelajaran ( 2 x 45 menit) yang diikuti 35 siswa yang terdiri dari 14 laki-laki dan 21 perempuan kelas X, pada tanggal 16 dan 23 April 2018. Kegiatan yang dilakukan selama proses pembelajaran pada siklus I pertemuan pertama yakni: Pada kegiatan pendahuluan, guru mempersiapkan kelas kemudian mendiskusikan kompetensi yang telah dipelajari dan menyampaikan materi yang akan disampaikan secara garis besar. Pada kegiatan inti, masuk ke dalam sintaks model pembelajaran discovery learning dengan prosedur sebagai berikut: 1) fase stimulation atau fase pemberian rangsangan. Pada fase ini, guru membagi kelas menjadi beberapa kelompok dengan jumlah 5-6 orang siswa, kemudian guru menampilkan slide presentasi yang berhubungan dengan konsep integritas nasional. Kemudian guru memberikan stimulasi dengan cara mengajukan pertanyaan yang dapat menghadapkan siswa pada kondisi internal yang dapat memotivasi siswa. 2) fase problem statement (identifikasi masalah). Guru memberikan kesempatan kepada siswa untuk menganalisis pertanyaan yang berkaitan dengan konsep integritas nasional. Kemudian guru membimbing dan mendorong rasa ingin tahu siswa. 3) fase data collection (pengumpulan data). Guru mengajak siswa untuk mengumpulkan informasi sebagai jawaban dari pertanyaan-pertanyaan yang telah dianalisis sebelumnya. 4) fase verification (pembuktian). Pada tahap ini guru meminta siswa untuk menghubungkan informasi yang diperoleh sebagai dasar untuk menarik kesimpulan mengenai 
konsep integritas nasional. Kemudian dilanjutkan dengan menyusun laporan hasil telaah, dan guru melakukan verifikasi hasil laporan siswa. 5) fase generalization (menarik kesimpulan). Guru membimbing siswa untuk melakukan generalisasi atau menyimpulkan hasil analisis laporan. Kemudian pada kegiatan penutupan guru melakukan refleksi dengan siswa mengenai pembelajaran yang telah dilaksanakan. Pada pertemuan kedua siklus I tahapannya sama seperti pada pembelajaran pertemuan pertama, namun pada akhir pembelajaran diberikan ujian siklus I.

3.

Hasil dari ujian siklus I disajikan pada Tabel

Tabel 3. Data Hasil Belajar Siswa Siklus I

\begin{tabular}{ccccc}
\hline \multirow{2}{*}{ No } & Hasil Tes & Prasiklus & \multicolumn{2}{c}{ Siklus I } \\
\cline { 4 - 5 } & & 90 & 90 & 80 \\
\hline 1 & $\begin{array}{c}\text { Nilai } \\
\text { Tertinggi } \\
\text { Nilai }\end{array}$ & 40 & 60 & 60 \\
2 & $\begin{array}{c}\text { Terendah } \\
\text { Nilai Rata- } \\
\text { rata }\end{array}$ & 70 & 81 & 65 \\
3 & Ketuntasan & $40 \%$ & $77 \%$ & $67 \%$ \\
\hline & Sedangkan kinerja guru dapat dilihat pada
\end{tabular}

Tabel 4.

Tabel 4. Data Hasil Kinerja Guru Siklus I

\begin{tabular}{ccc}
\hline No. & \multicolumn{2}{c}{ Aktivitas } \\
\hline 1 & Skor yang diperoleh & 92 \\
2 & Skor maksimal & 120 \\
3 & Presentase kerja & 76,6 \\
4 & Kriteria & Baik \\
\hline
\end{tabular}

\section{Deskripsi Siklus II}

Siklus II dilaksanakan pada tanggal 7 dan 14 Mei 2018, selama 2 × 45 menit $(2 \times$ pertemuan) yang di ikuti 35 siswa yang terdiri dari 14 laki-laki dan 21 perempuan kelas X. Evaluasi siklus II dilaksanakan pada tanggal 21 Mei 2018. Berdasarkan hasil evaluasi siklus II diperoleh hasil belajar siswa pada Tabel 5 .

Tabel 5. Data Hasil Belajar Kognitif Siswa Siklus

\begin{tabular}{cccc}
\multicolumn{4}{c}{ II } \\
\cline { 3 - 4 } No & Hasil Tes & \multicolumn{2}{c}{ Siklus II } \\
\cline { 3 - 4 } & & Kognitif & Psikomotor \\
\hline 1 & Nilai Tertinggi & 100 & 88 \\
2 & Nilai Terendah & 70 & 72 \\
3 & Nilai Rata-rata & 89 & 82 \\
4 & Ketuntasan & $91 \%$ & $86 \%$ \\
\hline
\end{tabular}
Tabel 6.
Tabel 6. Data Hasil Kinerja Guru Siklus II

\begin{tabular}{ccc}
\hline No. & \multicolumn{2}{c}{ Aktivitas } \\
1 & Skor yang diperoleh & 105 \\
2 & Skor maksimal & 120 \\
3 & Presentase kerja & 87,5 \\
4 & Kriteria & Sangat Baik \\
\hline
\end{tabular}

Pembahasan dalam penelitian tindakan kelas ini didasarkan atas hasil penelitian dan catatan guru selama melakukan penelitian. Secara terperinci pembahasan dari hasil penelitian pada setiap siklus dijabarkan sebagai berikut. Pelaksanaan model pembelajaran discovery leraning pada siklus I mendapatkan kategori baik untuk penilaian guru dan siswa. Namun terdapat beberapa hal perlu diperbaiki pada siklus I dan diharapkan dapat dilaksanakan pada siklus II, antara lain guru tidak menyampaikan model pembelajaran yang digunakan, ini mengakibatkan siswa merasa bingung terhadap model yang digunakan. Oleh karena itu pada siklus II guru menyampaikan semua tujuan dari model pembelajaran discovery learning yang akan dilaksanakan, karena hal tersebut sangat penting bagi siswa karena dapat meningkatkan kesiapan siswa dalam menerima dan memahami apa yang harus dilakukan dalam pembelajaran.

Dari hasil pengamatan siswa pada siklus I umumnya siswa kurang aktif dalam proses pembelajaran. Siswa masih kesulitan untuk bertannya, mengungkapkan pendapat atau menjawab pertanyaan. Untuk itu, dalam pembelajaran pada siklus berikutnya sebaiknya guru memberi penghargaan agar siswa lebih termotivasi untuk aktif.

Hasil belajar siswa yang diperoleh pada siklus I baik. Nilai rata-rata ulangan harian 81 naik sebesar 11 poin dari nilai rata-rata ulangan harian siswa sebelum penelitian yaitu sebesar 70 . Persentase ketuntasan belajar $77 \%$ naik $37 \%$ dari rata-rata ulangan harian sebelum pembelajaran $40 \%$. Sedangkan untuk aspek psikomotor sebesar 65 dengan ketuntasan $67 \%$. Walaupun demikian hasil tersebut belum sesuai dengan yang diharapkan, oleh karena hasil tersebut perlu ditingkatkan lagi pada siklus berikutnya.

Dari uraian di atas dapat diketahui bahwa semua indikator pembelajaran belum tercapai pada siklus I, oleh karena itu perlu dilaksanakan pada siklus II dengan beberapa perbaikan, antara lain dengan cara memberikan penghargaan bagi siswa yang aktif dalam pembelajaran atau memberikan motivasi bagi siswa yang kurang aktif dalam pembelajaran. Ini diharapkan banyaknya siswa yang aktif dalam pembelajaran lebih banyak. Selain itu optimalisasi guru dalam menjelaskan tujuan model pembelajaran. Ini diharapkan siswa tidak mengalami kebingungan terhadap model yang digunakan sehingga siswa siap dalam menerima 
dan memahami apa yang harus dilakukan dalam pembelajaran.

Pelaksanaan model pembelajaran discovery learning pada siklus II sudah menunjukan adanya peningkatan. Nilai rata-rata pelaksanaan untuk guru mendapatkan kategori baik sekali yaitu sebesar $87,5 \%$ sedangkan aktivitas siswa mendapat kategori baik yaitu sebesar 82,5\%. Dari aspek psikomotor mengalami peningkatan menjadi 82 atau ketuntasan menjadi $86 \%$. Dari pengamatan pada siklus II ditemukan siswa telah mampu mengikuti pembelajaran dengan baik. Hal ini terbukti makin banyaknya siswa yang aktif dalam bertannya maupun menyampaikan pendapat. Pada siklus II ini, guru juga sudah mampu memperbaiki kekurangan-kekurangan pada siklus I antara lain: guru sudah menyampaikan tujuan model pembelajaran yang digunakan, sehingga siswa merasa siap dengan apa yang harus dilakukan. Guru juga memberi motivasi kepada siswa agar selalu aktif dalam pembelajaran dengan cara memberikan penghargaan kepada siswa yang aktif dalam pembelajaran.

Hasil belajar siswa mengenai pemahaman nilai-nilai integrasi nasional yang diperoleh pada siklus II meningkat. Hal ini dapat diketahui dari nilai rata-rata kelas sebesar 89 meningkat sebesar 8 poin dari nilai rata-rata kelas pada siklus I yaitu sebesar 81. Persentase ketuntasan belajar juga meningkat dari $77 \%$ pada siklus I menjadi 91\% pada siklus II.

Pertemuan diakhiri dengan membagikan angket kepada siswa. Setelah angket dibagikan dan hasilnya di analisis, diperoleh data sebagai berikut: dari 35 responden, 30 responden $(85 \%)$ menyatakan model pembelajaran discovery learning sangat menarik dalam pembelajaran PPKn terutama dalam pemahaman konsep integritas nasional, 29 responden $(82,5 \%)$ menyatakan penggunaan model pembelajaran discovery leraning meningkatkan pemahaman nilai-nilai integritas nasional. Selain itu dengan melihat dari perolehan nilai dari aspek psikomotor, model problem based learning dapat meningkatkan psikomotor siswa sejalan dengan penelitian Nurtanto dan Sofyan (2015). Secara umum dapat disimpulkan bahwa siswa telah memiliki sikap yang baik terhadap nilai-nilai integritas nasional, khususnya melalui penggunaan model pembelajaran discovery learning. Semua indikator kinerja dalam penelitian ini sudah tercapai pada siklus II. Adapun ketercapaian indikator pembelajaran akibat beberapa faktor peningkatan yang disebabkan: (1) pengumpulan informasi secara terbimbing dalam sumber media online sejaln dengan penelitian Wartini et al (2014); (2) rasa ingin tahu, kreativitas, dan merumuskan pertanyaan kritis sejalan dengan penelitian Dharma dan Siregar (2014); (3) keberhasilan dalam mengkomunikasikan informasi. Walaupun sudah tidak ada penelitian lagi, guru mata pelajaran PPKn tetap melaksanakan model pembelajaran discovery learning dalam pembelajaran. Hal ini dikarenakan dari hasil penelitian ini model pembelajaran tersebut mampu meningkatkan hasil belajar siswa mengenai komitmen integrasi nasional. Komitmen integrasi nasional merupakan proses untuk menyatukan berbagai kelompok etnis dan sosial melalui simbol-simbol nasional dan ideologi yang menciptakan nilai-nilai yang sama dan identitas tunggal demi kesatuan nasional (Seman, Ahmad, Aziz, \& Ayudin, 2011).

\section{KESIMPULAN}

Pembelajaran PPkN dengan menggunakan model pembelajaran discovery learning efektif dalam meningkatkan pemahaman mengenai nilai-nilai integrasi nasional ditunjukkan pada siklus I diperoleh rata-rata kelas sebesar 81 dan pada siklus II sebesar 89. Adapun ketercapaian indikator pembelajaran akibat beberapa faktor peningkatan yang disebabkan: (1) pengumpulan informasi secara terbimbing dalam sumber media online; (2) rasa ingin tahu, kreativitas, dan merumuskan pertanyaan kritis; (3) keberhasilan dalam mengkomunikasikan informasi.

\section{UCAPAN TERIMA KASIH}

Ucapan terima kasih disampaikan kepada Kepala Sekolah SMK N 1 Cilegon, Bapak Widodo, M.Pd dan guru-guru yang membantu pemikiran dalam pelaksanaan Penelitian tindakan kelas.

\section{DAFTAR PUSTAKA}

Ali, M., \& Setiani, D. D. (2019). Pengaruh model discovery learning terhadap hasil belajar peserta didik pada konsep jamur. Bioedusiana: Jurnal Pendidikan Biologi, 3(2), 59-63.

Bonwell, C., \& Eison, J. (1991). Active learning: Creating excitement in the classroom. Washington, DC: George Washington University Clearinghouse on Higher Education.

Gainous, J., \& Martens, A. M. (2012). The effectiveness of civic education: are "good" teachers actually good for "all" students? American Politics Research, 40(2), 232-266. https://doi.org/10.1177/1532673X1141949 2

Lee, J. H. (2019). Learner instruction, attitudes during class and academic achievement of junior high school students in Korea: a panel analysis. Educational Studies, 45(2), 259-269. https://doi.org/10.1080/03055698.2018.144 6329 
Seman, A. A., Ahmad, A. R., Aziz, Z., \& Ayudin, A. R. (2011). The effectiveness of teaching and learning history based on multicultural towards national integration in Malaysia. Procedia Computer Science, 3, 1588-1596. https://doi.org/10.1016/j.procs.2011.01.054

Silberman, M. (1996). Active learning: 101 strategies to teach any subject. Allyn and Bacon.

Zmuda, A. (2008). Springing into Active Learning. Educational Leadership, 66(3), 38-42. 